\title{
John PREBBLE - A Titan of TAX
}

\section{Professor Dale Pinto*}

It is a great honour and privilege to share some of my reflections on Professor John Prebble - A Titan of tax, a gentleman and a great scholar.

I first met John at an Australasian Tax Teachers Association - or ATTA as it is fondly known conference in 1999. I was very nervous as I was presenting some early thoughts on my doctoral work on e-commerce and international tax.

John sat through my presentation quietly but looked on curiously and intently (like the detective 'Colombo') as he wrote down a couple of things - that is when I knew I was in trouble. When it came to the question-and-answer part of the presentation, up went John's hand and he asked me one or two questions. My heart was beating at a very fast rate, and I am sure I was trembling inside; nevertheless, what he asked was not only insightful but was put to me in such a constructive and helpful way.

I heard of John Prebble before I met him at this ATTA conference - the description that was relayed to me was "he is the Richard Vann from across the ditch". I took this as high praise as everyone knows what a towering intellect Professor Richard Vann is.

When I spoke to John the first time, I found him to be most personable and engaging. He was truly interested in what I was doing as part of my research and spoke most helpfully about different angles and ideas that I should consider. I am forever grateful to have had his wise counsel.

John's academic career is nothing short of exemplary and prolific. Apart from holding degrees from New Zealand, Oxford and Cornell University, he has authored or edited at least 12 books on tax and business law and has published over 200 articles in scholarly and professional journals. He is a former Trustee of the International Bureau of Fiscal Documentation (IBFD) and a member of the editorial boards of several scholarly journals. He has held research fellowships or visiting chairs at leading universities in the United Kingdom, Australia, Europe and the United States.

Professor Prebble has advised several governments on matters of tax reform and was a member of the New Zealand government's consultative committees on corporate taxation and international taxation in the 1980s and of the Committee of Experts on Tax Compliance in 1998. He has received

* Australasian Tax Teachers Association (ATTA) Life Member, Past President ATTA, Professor of Taxation Law Curtin Law School and Chair, Academic Board Curtin University, Western Australia. 
several awards, including the prestigious medal of the Australasian Tax Teachers' Association in 2006.

John's academic standing is well-known on both sides of the Tasman and internationally as well; but he is much more than an academic and in closing, I want to share two aspects of his personality which many may not know of.

The first is that John is an amazing mentor. Apart from my own experience that I noted above, I saw this first-hand when his niece, Zoë, presented a paper with him on Morality and Tax Avoidance - an interesting topic presented by an amazing double act. Zoë needed no help as it quickly became evident how intelligent and engaging she was. What I do remember is seeing John watch her presentation - with the same intent look on his face as when he sat in the audience to watch my first presentation - except this time not writing notes and the glow of pride was obvious in his face; and justifiably so.

The second is that John appears very serious but there is a humorous - no, hilarious - side to him that few know or have seen. I witnessed this when he was asked to be the after-dinner speaker at an ATTA conference.

On this occasion, I must confess that after a day of technical papers, I wondered whether John was the right choice. Sure, he would take the audience to another stratosphere in terms of tax, but could he hold an after-dinner crowd? Well, not only could he hold the crowd, but he finished his speech with the loudest acclamation I have ever heard. He made us laugh louder than I can remember, and his delivery style was so intelligent, insightful, engaging and simply hilarious. I will never forget this moment.

In conclusion, I feel privileged and honoured to have met John and learned from him but also to have discovered so much more about him and the many dimensions that make this Titan of Tax a caring mentor and someone who would be a formidable rival to the likes of John Cleese.

$\mathrm{He}$ is an asset to the tax profession, and I will never forget the impression he has made on me, both professionally and personally. 